\title{
STOCHASTIC EDUCATION IN CHILDHOOD: EXAMINING THE LEARNING OF TEACHERS AND STUDENTS
}

\author{
ANTONIO CARLOS DE SOUZA \\ Universidade Estadual Paulista - UNESP \\ toncaza@gmail.com \\ CELI ESPASANDIN LOPES \\ Universidade Cruzeiro do Sul \\ celilopes@uol.com.br \\ DÉBORA DE OLIVEIRA \\ Grupo de Estudos e Pesquisas em Educação Estatística e Matemática - GEPEEM \\ deboradeoliveira.mat@gmail.com
}

\begin{abstract}
This paper presents discussions on stochastic education in early childhood, based on two doctoral research projects carried out with groups of preschool teachers from public schools in the Brazilian cities of Suzano and São Paulo who were participating in a continuing education program. The objective is to reflect on the analysis of two didactic situations related to the learning of statistics in mathematics classes. The results show evidence of the mathematics learning of the teachers who teach mathematics in early childhood. They also highlight the mathematical and statistical relations that children are able to establish when carrying out stochastic activities included in their childhood context.
\end{abstract}

Keywords: Statistics education research; Stochastics; Early childhood education; Teacher education

\section{INTRODUCTION}

This paper starts from the premise that society's current needs demand from people more ability to deal with information and to make decisions. This emphasizes the importance of stochastic education from the early years of school. So, in this paper, statistics and mathematics are considered as interrelated sciences, offering people an interpretation of reality and its phenomena. In statistics, data are seen as numbers with a context (Cobb \& Moore, 1997) that triggers procedures, and also as a source of significations and a basis for interpreting results. Data uncertainty and randomness distinguish statistical investigation from the more precise but limited nature that characterizes mathematical experiences. Mathematical concepts and procedures are used to handle or 'solve' statistical problems, and some technical mathematical ability is expected in different classes and educational levels.

From this interaction between mathematics and statistics, this paper aims to promote reflections based on the analyses of didactic situations related to statistics learning in mathematics classes in preschool education. To do so, two activities are presented, developed by preschool teachers from public schools in the cities of Suzano and São Paulo, São Paulo state, Brazil. Both have doctorates in education (Oliveira, 2013; Souza, 2013). Their studies focused on building and mobilizing professional knowledge on teaching and learning stochastics in early childhood education.

\section{TEACHER EDUCATION AND LEARNING}

Statistics Education Research Journal, 13(2), 58-71, http://iase-web.org/Publications.php?p=SERJ (C) International Association for Statistical Education (IASE/ISI), November, 2014 
Teacher education is an ancient concern of society (Imbernón, 2010) that began when someone decided that their children's education would be taken care of by another person. However, worrying about how this is carried out, what knowledge and models will be used in the process, which educational model is the most innovative, and being aware that educational theories and practice should be updated, is, according to Imbernón (2010), something new. When considering a teacher's pedagogical model, the context in which the teacher's knowledge is built and applied should be taken into account, and the historical and social background, as well as the basic teaching conditions in which the profession is practiced, should be considered (Bezerra, 2011).

Ideas regarding in-service education of teachers and the education future teachers has changed over time. These changes are due to the influence of different societal contexts and needs, which have also changed throughout history. Formative moments (Nacarato, 2000) can occur in different spaces, such as group discussions, pedagogic meetings, and development of pedagogical projects, or even during broader discussions, such as congresses, educational symposiums, teachers' professional development classes, extramural courses, postgraduate courses, and others. Imbernón (2010) says that education must offer a process that enables teachers to learn how to learn, but also to learn how to unlearn through communication, selfanalysis, and self-discipline, mobilizing knowledge, abilities and behavior in order to develop restless and innovative professionals, people who will learn from their successes and their mistakes.

Teachers are professionals who, according to Tardif and Raymond (2000), have been at school - their workplace - for approximately 16 years before starting work. At the end of their qualifying course, when they are ready to work, they must avoid the thought that "I have already concluded my studies." 'Concluding' may suggest that studying is no longer necessary, as if they have already reached a level from which there is no further learning available (Furlanetto, 2007). Yet, concluding the course does not mean concluding education. Throughout their lifetime, they will need to keep learning, and so they must consider differences in learning style, and in time, place and pace of learning (Statonato, 2010). This may apply to their personal and professional lives, since, according to Freire (1996), we are 'unfinished beings'.

Therefore, considering teachers as 'unfinished' professionals (Jesus, 2011) may lead to a different way of viewing them, as well as their education, going beyond the training-based educational perspective. According to Silva (2009), teachers' learning is formed in a complex way; it is non-linear, and influenced by various factors - personal, collective, cultural, emotional, cognitive, psychological, and social.

To Placco and Souza (2006) adult learning involves an intense affective interaction. On the one hand, it implies accepting that one doesn't know everything, or knows only partially or even incorrectly; on the other, it is related to the pleasure of discovering, creating, inventing, and finding answers to what one has been looking for - to new knowledge, ideas and values.

Adult learning is a result of interaction among adults, in which experiences are interpreted, knowledge is acquired, and actions are triggered (Placco \& Souza, 2006). In the case of teachers, such interaction happens among them and their coworkers, whether in meetings, discussions, chats (even informal ones), planning, classes, studies and others. Within those spaces, the teacher may confront ideas and actions; it is possible to try, to be right or to be wrong, and to listen to others' experience. Yet, there are situations that favor individual learning: studying theories and questioning them; reflecting on one's practice and way of thinking; using memory to recall experiences and knowledge.

In this way, a person learns within a historical-cultural context, building his or her own unique ways to assimilate and transform the information around him or her into knowledge. The complexity of the learning process is related to recognizing the diversity that characterizes learning, whether individual aspects such as wishes, motives and styles, or political aspects such as pedagogical content and methodologies (Batista, 2008).

Adult learning is motivated by internal and external factors. Among the internal factors mentioned by Placco and Souza (2006), we highlight those referring to wishes: interests, commitments, needs, curiosities, and enthusiasm - understood by us as commitment to one's 
profession and self, need to solve exasperating situations, and enthusiasm in learning. Among the external factors mentioned, we point out those referring to mutual aid, the nature of knowledge nature, the ongoing challenge, and the sociopolitical-pedagogical context.

Starting from these assumptions we emphasize that, in order to learn, some conditions must be considered: readiness for new experiences, willingness to recognize oneself, flexibility and sensitivity. It must also be considered that what is to be learned has to make sense to the individual in the context of his or her learning and knowledge, and, at the same time, to mobilize his or her interests, motives, and expectations.

\section{STOCHASTIC EDUCATION: THEORETICAL ASPECTS AND TEACHING IN CHILDHOOD}

According to national curriculum documents for mathematics (Brasil, 1997), studies concerning notions of statistics, probability, and combinatorics for elementary education, presented under the heading of 'processing information', aim to approach the subject without relying on definitions of terms or formulas. Thus, the objectives of studying these topics are:

- Statistics: to construct procedures that collect, organize, communicate and interpret data using tables, charts and everyday representations.

- Probability: to understand that most events of everyday life are random, and that it is possible to identify probable outcomes. Notions of chance and uncertainty can be explored at school by performing experiments and observing events.

- Combinatorics: to lead students to deal with problem situations that involve combinations, arrangements, permutations and the multiplicative principle of counting.

However, the National Reference Curriculum for Preschool Education (Brasil, 1998) does not mention addressing notions of statistics, probability, and combinatorics in preschool education. We have discussed ideas of stochastic education in our studies and we defend the idea of implementing them in early childhood, considering that the process of analyzing data offers children multiple readings of their culture.

Davis and Hersh (1998) consider the current world a stochastic one when one adopts a point of view in which uncertainty (chance or probability) is accepted as a real, objective and essential aspect of the world. The authors argue that 'stochastic' is an umbrella term referring to a whole conceptual system of practical or theoretical, philosophical or methodological elements, whose dominant feature is uncertainty. In Brazil, the term 'stochastic' has been used by Lopes throughout her studies (1998, 2003, 2010, 2011, 2012).

It is very important to develop stochastic education starting in early childhood, since children also live in a stochastic world and so will learn about it through their experience. Mathematical knowledge, including stochastic knowledge, is a human construction, and as such, it can and should be offered to children from preschool. But in order to achieve this, teachers must be educated to include it in their practice.

\subsection{SOME IDEAS ABOUT STOCHASTICS}

The constant presence of statistics in the contemporary world has become a reality of citizens' lives, making the teaching of statistics necessary to a growing number of people (Lopes, 2010). According to Shaughnessy $(1992,1996)$, citizens of modern societies must have competence in statistics, so that they can be critics of the available information, understanding and communicating based on this information. Thus, the inclusion of statistics in the mathematics curriculum stems from the social demand for production of large amounts of information, requiring people to analyze it carefully and quickly, and to focus quickly on relevant aspects (Lopes, 2008a).

The complexity of the contemporary world, the changes and transformations of social and economic reality, require statistical analyses of observed information (Coelho \& Carvalho, 2008). Thus, teaching statistics is not restricted to definitions and charts, but must include the 
interpretation and critical analysis of such data in order to discover contradictions and to develop distrust of misleading evidence.

In this regard, Garfield and Gal (1999) argue that the main objective of statistics education is to develop statistical reasoning skills in students - that is, citizens - enabling them to produce and communicate descriptions, judgments, inferences, and opinions about any information.

Statistical knowledge embraces, according to Lopes (2008a), statistical reasoning, statistical literacy, and statistical thinking - this last is strongly related to the first two items. The acquisition of statistical knowledge can assist individuals in analyzing the data generated in discussions of information, enabling them to understand their reality, immersed in complex contexts.

For Garfield and Gal (1999), statistical reasoning is a way of thinking starting from statistical ideas, thus giving meaning to statistical information. It involves making interpretations based on information, on representations and statistical summaries of data.

Lopes and Carvalho (2005) consider statistical literacy as the ability to interpret statistical arguments in newspapers and other information sources. It is a skill that is more than computational, growing through numerical literacy, and necessary to people who are constantly in touch with data about which they have to make decisions.

\subsection{STOCHASTIC EDUCATION IN CHILDHOOD}

Writing about mathematics education in early childhood, Souza (2007) notes that drawing numerical symbols is not enough to guarantee the development of numerical concepts in children. In statistics, working with charts and tables does not guarantee the construction of statistical knowledge, whether in a child, teenager or adult. Thus, we understand statistical literacy as the ability to interpret, evaluate and interact with statistical information. The importance of its development in people's lives, especially in the lives of ordinary citizens, corresponds to the full development of reading and writing skills in one's native language. According to Coelho and Carvalho (2008), the critical analysis of statistical information can be encouraged from elementary school as an important basis for preparing students to make decisions autonomously and safely.

According to Lopes (2008b), traditional teaching of mathematics focuses on accuracy, determinism and calculation, in opposition to the use of situations involving approximation, randomness and estimation. This may limit the potential mathematical vision of a student and, according to the author, may hinder their chances of developing strategies to solve the various problems they will face in their lives.

Content related to statistics, probability, and combinatorics has been introduced into the mathematics curriculum of Brazilian elementary schools since the 1990s (Costa \& Nacarato, 2011), and was greatly emphasized after the publication of the National Curriculum (Brasil, 1997). The authors point out that this occurred later than in many other countries, and teachers had no prior training in ways of introducing the subject in elementary school. Ponte (1992) points out that teachers ought to have an inventory of knowledge - scientific, professional, and general - to properly develop their work in the classroom.

If teachers did not have any significant experience in a particular field of knowledge during their initial education and training, they are likely to feel unsafe about incorporating it in their practice (Costa \& Nacarato, 2011). Teachers need to see themselves as the protagonist of their classroom activities, rather than merely applying activities prepared by someone else. In this sense, Lopes (2008a) considers that a major concern in current research on stochastic education refers to the education of the teachers.

Reflecting on teacher training, it is in their work that teachers develop and build knowledge, which is expanded and constructed within the relationship and interaction between the spheres of work and everyday life (Cazorla \& Castro, 2008). Pamplona and Carvalho (2011) argue that learning is what changes our ability to experience practice; it makes it possible to understand why we do what we do, and which resources we have at our disposal to do so. However, according to Perez (1999), a theoretical foundation is necessary to gives teachers a position to 
understand the rationale of various methodologies. Also needed is an ability to use a variety of strategies depending on the goals.

Mathematics classes that focused on contexts that were inconsistent with students' reality and needs have been common for some time. Since statistics is taught in mathematics classes, there has not been enough space to develop statistical knowledge effectively. As a result, elementary school teachers, especially preschool and early childhood educators - whose statistical and mathematical knowledge is based on the training received at their own elementary school - do not consider themselves prepared to introduce statistical ideas in their classes.

\section{METHODOLOGICAL PATHWAYS: DEVELOPED ACTIVITIES AND MOBILIZED LEARNING}

In his doctoral research, Oliveira (2013) worked with a group of 13 teachers who teach in early childhood education or in the early years of elementary school. He sought to investigate, in the context of teacher training, the learning revealed by teachers who teach mathematics to children, focusing on stochastic aspects.

In this context of continuing education, an interactive movement occurred between the teachers and the teacher-educator-researcher. Teachers narrated their experiences in school, when they were working with students and immersed in a process of linking theory and practice. Meanwhile, the teacher-educator-researcher prompted a process of reflection by theoretical interventions resulting from his immersion in a cycle in which he was "constantly fed by queries to bibliographic sources, by various dialogues we carry out with other researchers interested in the same questions, in research groups, at conferences, meetings" (Lopes, 2003, p. 103).

Work with the teachers consisted of discussing a concept, structured around questions proposed by the teacher-educator-researcher based on activities involving the concept. On the basis of this, the teachers prepared an instructional sequence that would be used in the classroom and then presented it to the group for discussion and analysis. Gradually, a rich space was built for reflective discussion, based on collaborative activities developed by teachers, and recorded by them in their own classrooms in the form of videos, photographs, and written documents.

The documentation on which the data analysis was based consisted of:

- Profile questionnaire: Information on the role of the teacher, his/her experience of teaching, knowledge about statistics and probability during the initial training, participation in continuing education for mathematics and/or statistics, and classroom actions involved in developing teaching activities on the ideas of statistics and probability.

- Audio recordings: The training meetings were recorded with a device that sat motionless on a nearby table; for data analysis all recordings were transcribed.

- Activities undertaken by the teachers: classroom teaching sequences that should be carried out. For everyone to have access to the activities proposed in class, group discussion of the activities was requested.

- Narratives written by teachers about the activities and their influence in school: these complemented the recorded discussions of the training sessions, and provided evidence of reflective action in school practice.

During this process, teachers had the experience of interpersonal reflection during the meetings, and self-reflection in preparing narratives about their implementation of the activities (Ibiapina, 2008). It was noticed that the space of formative action set up by the researcher and transformed throughout the process by all participants contributed "to configure the uniqueness of being a teacher, while supporting them to become more responsible and more aware, not only of the work of teachers, but also of their ability to transform it" (Ibiapina, 2008, p. 51). In this paper, we present an instructional sequence entitled "A doll and her name", developed by teachers $\mathrm{V}$ and $\mathrm{T}$ for children four to five years old. 
In another doctoral research project, Souza (2013) studied a group of six teachers who teach in early childhood education and in the first year of elementary school. He analyzed the ways in which their learning centered in reflective practice can help them to include stochastic aspects in their practice of childhood education.

The participating teachers talked about their own difficulties with mathematics, and so also statistics. For almost all of them this occurred throughout elementary school and high school, and their university education did not resolve their problems, especially as most of them studied pedagogy, which given little emphasis to mathematics and statistics.

The difficulties they reported affected their professional performance, because they could not tackle statistical and mathematical ideas in their classes with any confidence. However, it was noted in the teachers' narratives that some strategies (such as reading stories and play activities) used for topics in other areas of knowledge could also be used to introduce ideas in stochastic education. However, the teacher-educator-researcher simply pointing out the existence of such strategies was not sufficient for the participating teachers to begin work related to stochastic education.

The teacher-educator-researcher suggested the reading and discussion of reports written by other teachers who had experience of classroom work with stochastic education. In this way, the participating teachers realized that they already included some mathematical and statistical ideas in their classes, even if unintentionally. What was missing was the knowledge needed to carry out the work intentionally. During this process of teacher education, opportunities were made for the teachers to carry out readings, discussions, experiments, solving problems, and other actions aimed at the construction of mathematical and statistical knowledge needed to improve their professional practice.

To verify the effectiveness of this approach, the teacher-educator-researcher proposed that each teacher prepare a didactic sequence on the topic discussed. In this paper, we present one of these, a didactic sequence titled "Green, blue and little red ones", developed by teacher S with her five-year-old students.

Thus, the discussion in this paper focuses on two studies conducted with collaborative groups in which researchers worked together with teachers to contribute to their professional development, planning teaching sessions and helping the teachers to cope with the complexity of daily educational situations (Ibiapina, 2008). The teachers collaborated with researchers in a process of socializing their experiences and reflecting on their practices, allowing them to understand the inherent conflicts in the work of teaching and to reinterpret the theory based on the socialized practices.

\subsection{A DOLL AND HER NAME}

Teachers $\mathrm{V}$ and $\mathrm{T}$ developed an activity that aimed to introduce the topic of ethnic-racial relationships. They took to class a black doll, which would be looked after by a different pair of students each day (Figure 1). Through daily contact with the doll, children talked about different dolls and their physical aspects.

Then, the children listened to a poem entitled "eugenia," from Tereza (2007, p. 85).

\section{eugenia}

Clarice's black doll should not be touched, it was forbidden

to play with it because it really appeared to be

a black baby, bright soft skin, textured hair.

Eugenia was a gift Clarice's mommy had hated.

And yet, by pure erudite delight, she baptized her

With small letters, unaccented, eugenia. 


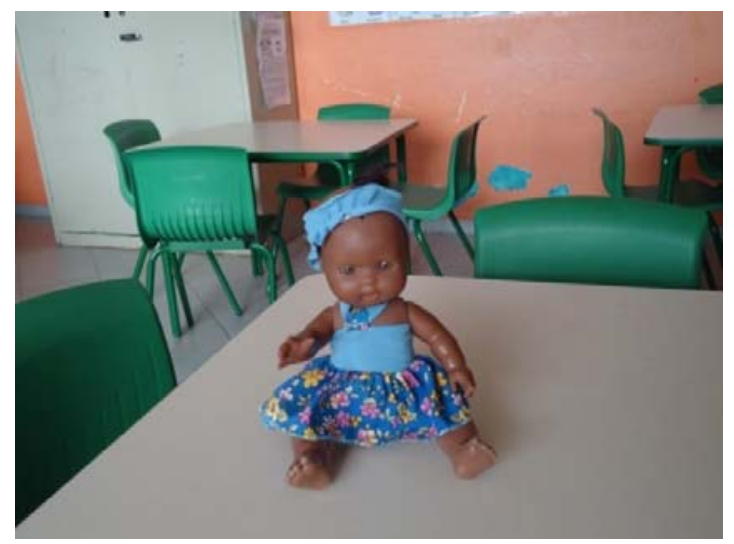

Figure 1. The black doll.

As the poem was about a doll that was given a person's name, the children were asked to choose a name for the doll in their class. The teachers asked them to suggest names for the doll, giving some suggestions themselves (Figure 2), and the children were invited to vote.

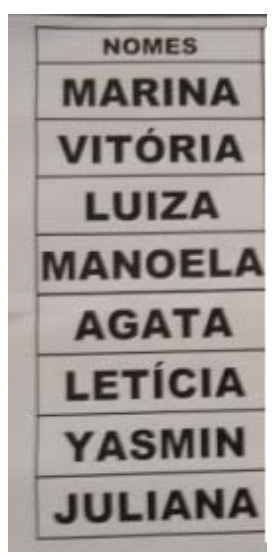

Figure 2. Suggested names for the doll.

The teachers created a column chart where each suggested name had a color. The children chose one name and glued a rectangle of the corresponding color onto the collective chart (Figure 3).
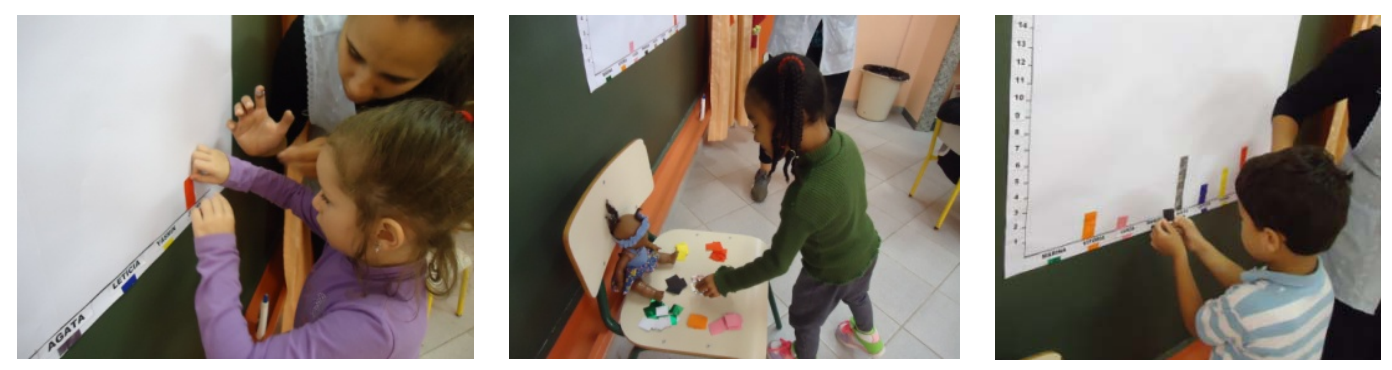

Figure 3. Making the display of results.

At the end of the survey, children identified the doll's chosen name by observing the highest column, as shown by Figure 4. 


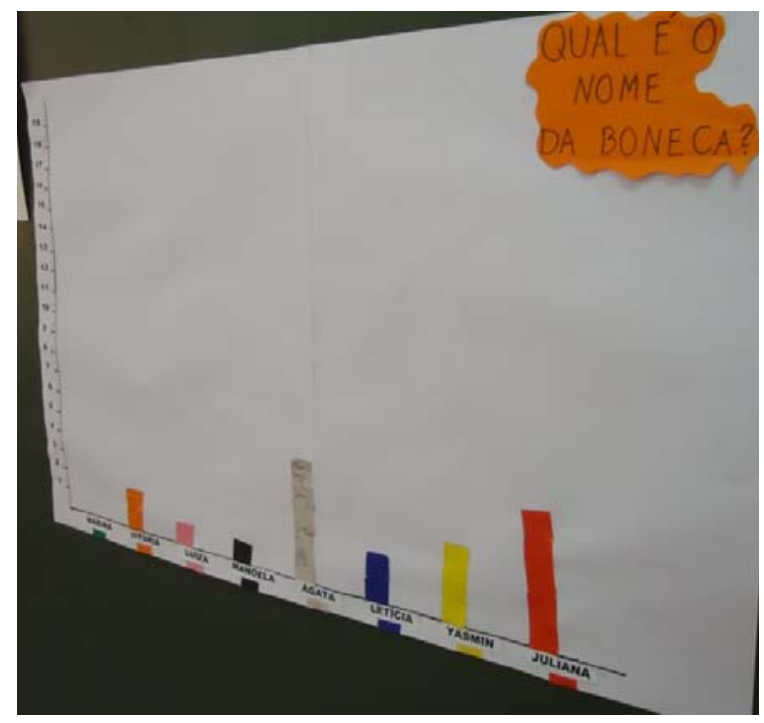

Figure 4. What is the doll's name?

But there was a tie in the votes, and the children soon identified that Agata's and Juliana's columns were the same height. One of the teachers proposed a new survey to break the tie:

I started by reading the poem again and recalling the previous day's results. I realized that I made a mistake when drawing the chart, and pointed this out to the class. Our chart lacked a title; but soon suggestions were made: "Doll's chart," "Doll's name," and during the discussion we decided that the title would be "What is the doll's name?" So we developed a new chart, different from the previous one ("What is the name of the doll? Tiebreaker"), and from the 18 children there, 10 voted for Agata and 8 voted for Juliana. When they were asked about which name won and why, they knew how to explain clearly. "In order for Juliana to win, like Agata, it lacked 2." "Who won was Agata was because it reached 10." (Teacher T)

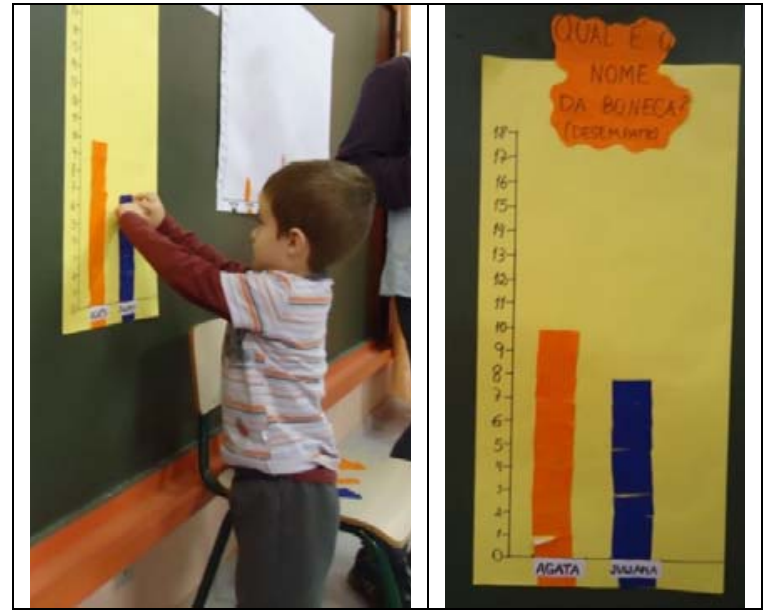

Figure 5. The tie-breaker.

At the end of the project, teacher $\mathrm{V}$ wrote about the activity:

I did a project with teacher $\mathrm{T}$ that has surprised us with its results. We were able to unite two topics that have been studied in parallel: "Mathematical Education for Children - a look at Stochastics" and "Education on Racial-Ethnic Relations." 
In short, we worked with a poem ("eugenia") that is about a black doll. We took to class a black doll that had no name. Our task was to find a name for the doll and to conclude the project by writing a poem about it. Children gave some name suggestions that were listed in a table, to initiate voting. At the end of the project, the information collected was represented in a graph filled by the students themselves. The analysis performed by some students at the end was fantastic.

We are about to finish the course, and I already have another project in progress, which, of course, will include mathematics. It is named "Atlantic Forest First Steps - The Jaguar Buddies."

The progress my work reached is clear, and I do not intend to stop it when the course ends. I intend to continue researching and creating situations that include stochastics in my work with children. (Teacher V)

Developing an activity, writing about it, sharing it with a group, and writing about its process of formation "may trigger propositions, initiatives, feelings and concerns. These resources allow memory's movement, which can mobilize learning both in teachers and in their students" (Placco \& Souza, 2006, p. 37). This is what happened to teachers V and T, who, throughout their narrative, described the process of developing an activity that involved actions, thoughts, movements, and instructional choices.

We point out that in this activity we can observe, as Garfield and Gal (1999) propose, the work of the teachers in developing the statistical reasoning of the children.

\subsection{GREEN, BLUE, AND LITTLE RED ONES}

Teacher S developed an activity in which she used the book Verdes, azuis e vermelhinhas (Green, blue and little red ones, Dias, 2009), which is about Belinha, a girl who plays with a jar of marbles at her father's workplace. The teacher asked her students to construct, compare and discuss charts based on Belinha's experience when she spread the marbles out on the floor. While performing the activity, the teacher shared with our group her questions and successes:

I'll tell you what I've done so far; as I said, I'm trying... There's a book that I read to the children, called "Green, blue and the little red ones". It is about a girl who goes to her father's workplace, where he keeps a jar full of marbles on the top of a bookcase. She enjoys going to her father's workplace to play with the marbles. They are colored marbles; they could be blue, green or red. I've told this story a few times to my students, and I have also made some charts with them. So far, I've made the chart and they have copied it. (Teacher S)

The charts were collectively built (like those created in the activity of teachers $\mathrm{V}$ and $\mathrm{T}$ ). Teacher S drew a picture of a girl (Belinha) with a jar and 22 small circles representing the marbles scattered on the ground. She also included three columns of the same height, divided in 22 parts, as shown in Figure 6.

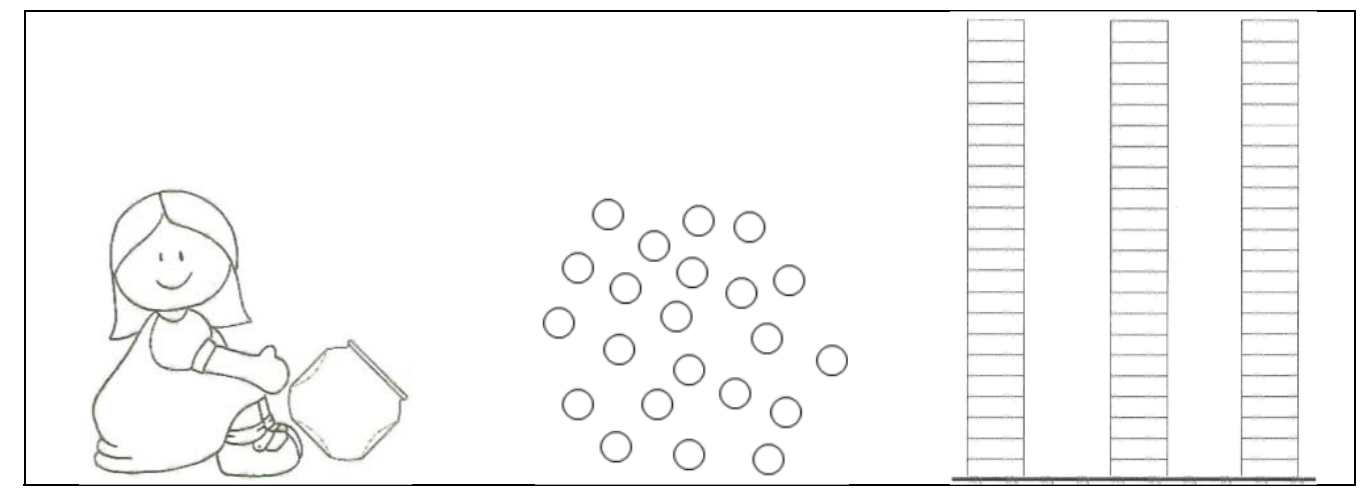

Figure 6. Model of the activities. 
We observed that in each of the three columns, one for each value of the variable 'marble colors' (green, blue or red), there were 22 subdivisions, equal to the total number of marbles. The teacher took into account something we had already discussed: when creating a column chart it is possible to have, as a final result, one of the columns with the maximum frequency, corresponding to the total number, as well as columns with frequency equal to zero.

To perform the activity, students colored the marbles as they pleased, choosing from the three colors, as shown in Figure 7.
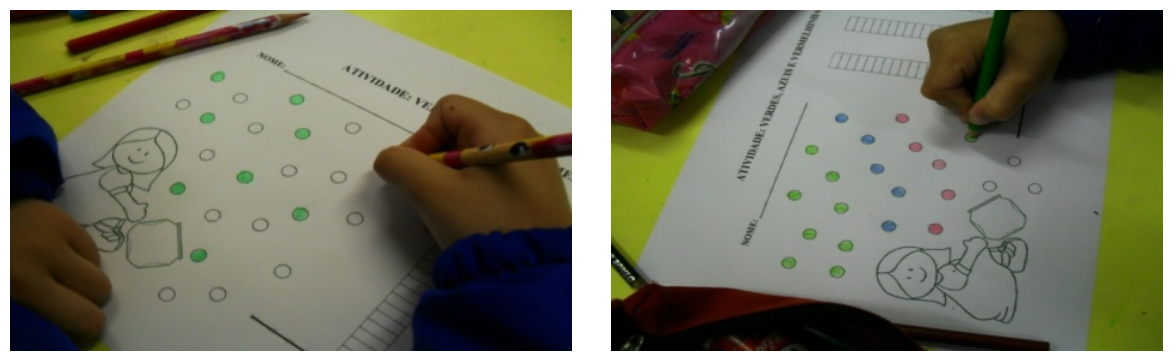

Figure 7. Coloring marbles.

Once the marbles were painted, students painted the columns, one column for each color, with number of segments corresponding to the frequencies of marbles of that color (Figure 8).
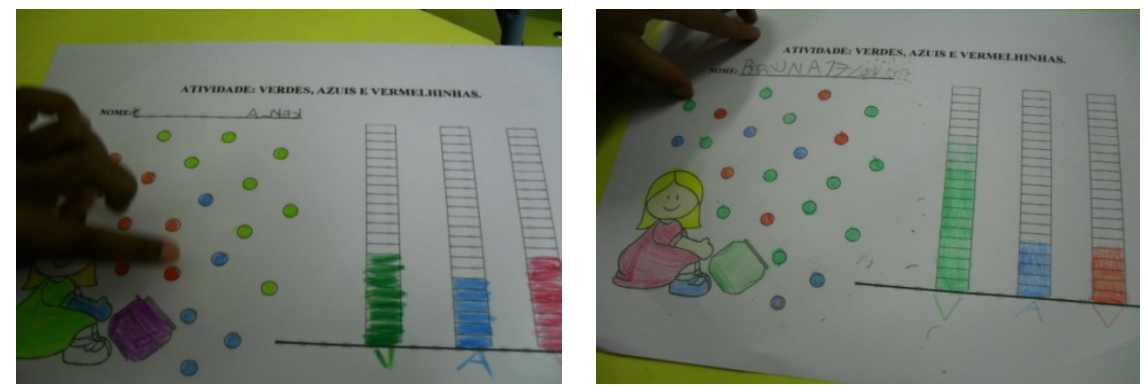

Figure 8. Bar graphs.

When reporting the activity to the group, teacher S said she felt uncomfortable because she thought that her project was all about charts, and she would also like to do activities linked to combinatorics and probability. In discussion with the group, she realized that she could have explored some ideas of combinatorics, for example, the sequence of colors in the columns of the chart. The sequence actually used was probably influenced by the title of the book (Green, blue and little red ones). A point suggested for discussion with her students was: which sequences can be formed with the colors green, blue and red?

The activity finished with a comparison and a discussion between the teacher S and her students about their different answers; at this point, they were discussing some ideas of combinatorics, although unintentionally. Figure 9 shows the students comparing their results.

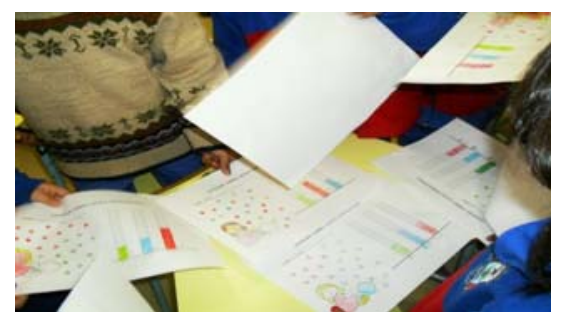

Figure 9. Comparing the bar graphs. 
The teacher was asked to tell us about her impressions of the activity:

It was very interesting, I really like working with stories. My students were dazzled by the fact that each one had a different chart. Every now and then, someone was asking, "But how many marbles must be blue?" I answered, "I don't know, it is your decision." "Then I can paint eight?", the student asked. Another said: "I want three." I already had a feeling that this was going to be a lot of fun, right? It was really cool, very different. We even discussed the favorite color: those who liked blue, colored the marbles in blue, those who liked green, chose to use green....Another interesting thing, I had already told this story several times, so I realized that we can use anything to teach mathematics. When I saw that jar of balls scattered in the book, I thought, "Wait, why do I have to determine the number of each color? If I behaved like before I would certainly say, "I want you to color so many balls in that color"... So for me, it was wonderful. When students compared their charts, they said, "So, teacher, does it means that charts can be different?" I loved it, because until that moment they thought that the charts must be the same for everyone." (Teacher S)

In this activity we can see that the children had opportunity to development some abilities needed to deal with statistical information from their own context, as recommended by Lopes (2012). In her report, teacher S exposes some of her feelings, such as joy to do something different in her practice and to notice a change, as well as the fear that kept her from experiencing something that maybe she had not fully realized. As Placco and Souza (2006) claimed, learning involves intense affective interaction.

\section{DISCUSSION AND CONCLUSION}

At the beginning of the work discussed here - in interviews and initial group meetings - it became evident that teachers had little familiarity with statistics, probability and combinatorics. Their only knowledge of working with statistical information came from their own experiences as students in elementary school, and, according to their reports, the training they received in high school and university did not add significantly to this knowledge. Using only their common-sense ideas, they believed that it was not possible to address concepts related to stochastics in early childhood education.

However, during the work, changes in their knowledge became evident. Feelings of fear and insecurity gave way to confidence, and with it the understanding that the approach was feasible and possible.

The work of the groups gave rise to new ways of understanding the content, leading to increased awareness of ways of approaching ideas of stochastics in their classes, even though it was often unintentional. This lack of intentionality was related to the absence of a mathematical and statistical knowledge that could have allowed them to understand what they were doing.

Such intentionality gives the teachers opportunity to reflect on their work. Thus, they are able to perceive their own potential, the points that need attention and why. At the same time when the acquired knowledge is mobilized, new knowledge emerges, providing the teacher with an enhanced ability to establish relationships and to intervene in students' practices.

The process of analyzing the data from the two projects allowed us to emphasize evidence of teachers' knowledge construction resulting from interactions with peers in the group and with their own students. This supported them while they reconstructed their conceptions about mathematics, stochastic education, and their teaching strategies. It is also important to note that teachers showed evidence of learning by doing, when they engaged as critical consumers of their own teaching materials, and assumed critical positions towards their own productions.

In both projects described here, the teaching and learning resources used by the teachers to include stochastic ideas in their classes were based on their classroom contexts, on the childhood stories. This revealed how new professional knowledge was mobilized, expanded and/or constructed during this process. By acting this way, the teachers set themselves up as initiators of their learning and, consequently, of the professional development process itself.

In the development of the two projects, we found that the teachers' participation in their respective groups contributed to the expansion of their professional knowledge and provided an approach to stochastic education; together, the teachers shared experiences, and they had their 
work valued and appreciated by their peers. They shared their thoughts and emotions about what they did not yet know and about what they felt unable to do, they found support to transform their uncertainty into certainty (Freire, 1996), and they reflected on their practice, in a way that yielded changes.

The results give evidence that a process of teacher professional development centered on reflection about their teaching practices can contribute to the inclusion of ideas of stochastics in childhood education. They also highlight the possibilities that are created by teacher education which considers teachers themselves as collaborative producers of professional knowledge. Furthermore, the results emphasize to teachers that they can consider their classrooms as spaces to construct new knowledge.

\section{REFERENCES}

Batista, S. H. S. S. (2008). Formação de professores e aprendizagem: tecendo encontros. [Teacher training and learning: weaving meetings.] Revista@mbienteeducação, 1(1). [Online:

arquivos.cruzeirodosuleducacional.edu.br/principal/old/revista_educacao/pdf/volume_1/art4sylvia.pdf ]

Bezerra, M. M. (2011). Formação docente e emancipação humana: narrativas orais com fins de pesquisa social. [Teacher education and human emancipation: oral narratives for social research]. Paper presented at the $5^{\text {th }}$ Brazilian meeting of Education and Marxism: Marxism, education and human emancipation, Florianópolis, Brasil, April 11-14.

Brasil Secretaria de Educação Fundamental (1997). Parâmetros Curriculares Nacionais: Matemática [National Curriculum Parameters: Mathematics]. Secretaria de Educação Fundamental. Brasília, Brasil: MEC/SEF. [Online: http://portal.mec.gov.br/seb/arquivos/pdf/livro03.pdf]

Brasil (1998). Ministério da Educação e do Desporto. Secretaria Fundamental de Educação. Referencial Curricular Nacional para a Educação Infantil. [National Reference Curriculum for Preschool Education.] Brasília, Brasil: MEC/SEF.

Cazorla, I. M., \& Castro, F. C. (2008). O papel da estatística na leitura do mundo: o letramento estatístico [The role of statistics in reading the world: statistical literacy]. Publicatio Ciências Humanas, Linguística, Letras e Artes, 16(1), 45-53.

Cobb, G. W., \& Moore, D. S. (1997). Mathematics, statistics, and teaching. The American Mathematical Monthly, 104(9), 801-824.

Coelho, M. A. V. M. P., \& Carvalho, D. L. (2008). O ensino da estatística na escola básica: mobilizando o conhecimento da prática dos professores. [The teaching of statistics in schools: mobilizing knowledge of teachers' practice.] Presented at $12^{\circ}$ Encontro Brasileiro de Estudantes de Pós-Graduação em Educação Matemática. Rio Claro, Brasil, September 5-7 [Available in CD-ROM].

Costa, A., \& Nacarato, A. M. (2011). A estocástica na formação do professor de matemática: Percepções de professores e de formadores. [Stochastics in mathematics teacher education: Perceptions of teachers and trainers.] Bolema, 24(39), 367-386.

Davis, P. J., \& Hersh, R. (1998). O Sonho de Descartes: O mundo de acordo com a Matemática [Descartes' dream: The world according to mathematics]. Translated by M. C. Moura. $2^{\text {nd }}$ ed., Rio de Janeiro: Francisco Alves.

Dias, V. L. (2009). Verdes, Azuis e Vermelhinhas [Green, blue and little red ones]. São Paulo, Brasil: Elementar.

Freire, P. (1996). Pedagogia da Autonomia: Saberes necessários à prática educativa [Pedagogy of Autonomy: Necessary knowledge for educational practice]. São Paulo, Brasil: Paz e Terra.

Furlanetto, E. C. (2007). Como Nasce um Professor?: Uma reflexão sobre o processo de individuação e formação [How a teacher is born: A reflection on the process of individuation and training] ( $4^{\text {th }}$ ed.). São Paulo, Brasil: Paulus.

Garfield, J., \& Gal, I. (1999). Teaching and assessing statistical reasoning. In L. Stiff (Ed.), Developing mathematical reasoning in grades K-12 (pp. 207-219). Reston, VA: National Council of Teachers of Mathematics. 
Ibiapina, I. M. L. de M. (2008). Pesquisa Colaborativa: Investigação, formação e produção de conhecimentos [Collaborative Research: Investigation, training and knowledge production]. Brasília, Brasil: Líber Livro.

Imbernón, F. (2010). Formação continuada de professores [Teachers' continuing education]. Porto Alegre, Brasil: Artmed.

Jesus, C. C. (2011). Análise Crítica de Tarefas Matemáticas: Um estudo com professores que ensinam matemática nos anos iniciais do ensino fundamental [Critical Analysis of Mathematical Tasks: A study of teachers who teach mathematics in the early years of elementary school]. Master's thesis in Science Teaching and Mathematics Education. Universidade Estadual de Londrina, Brasil.

Lopes, C. E. (1998). A Probabilidade e a Estatística no Ensino Fundamental: Uma análise curricular. [Probability and Statistics in Elementary School: A curricular analysis.] Master's thesis in Education. Universidade Estadual de Campinas, Brasil.

Lopes, C. E. (2003). O Conhecimento Profissional dos Professores e suas Relações com Estatística e Probabilidade na Educação Infantil. [The Professional Knowledge of Teachers and their Relationships with Statistics and Probability in Preschool Education.] Ph.D. thesis. Universidade Estadual de Campinas, Brasil.

Lopes, C. E. (2008a). Reflexões teórico-metodológicas para a educação estatística. [Theoretical and methodological reflections on statistics education.] In C. E. Lopes \& E. Curi (Eds.), Pesquisas em Educação Matemática: Um encontro entre a teoria e a prática. [Research in Mathematics Education: An encounter between theory and practice] (pp. 67-86). São Carlos, Brasil: Pedro \& João Editores.

Lopes, C. E. (2008b). O ensino da estatística de probabilidade na educação básica e a formação de professores [Teaching statistical probability in elementary education and teacher training]. Cadernos Cedes, 28(74), 57-73.

[Online: http://www.cedes.unicamp.br]

Lopes, C. E. (2010). Os desafios para educação estatística no currículo de matemática. [Challenges for statistics education in the mathematics curriculum.] In C. E. Lopes, C. Q. S. Coutinho, \& S. A. Almouloud (Eds.), Estudos e Reflexões em Educação Estatística [Studies and Reflections on Statistics Education] (pp. 47-64). Campinas, Brasil: Mercado das Letras.

Lopes, C. E. (2011). Educação estocástica nas aulas de matemática e a resolução de problemas [Stochastic education in mathematics classes and problems solving]. Seminário em Resolução de Problemas (SERP), 2, November, 10-11, UNESP de Rio Claro, Anais. [Online: http://www2.rc.unesp.br/gterp/sites/default/files/artigos/completo-celi_lopes.pdf]

Lopes, C. E. (2012). A educação estocástica na infância [Stochastic education in childhood]. Revista Eletrônica de Educação, 6(1), May.

[Online: http://www.reveduc.ufscar.br/index.php/reveduc/article/viewFile/396/179]

Lopes, C. E., \& Carvalho, C. (2005). Literacia estatística na educação básica [Statistical literacy in basic education]. In C. E. Lopes \& A. M. Nacarato (Eds.), Escritas e Leituras na Educação Matemática [Writing and Readings in Mathematics Education] (pp. 77-92). Belo Horizonte, Brasil: Autêntica.

Nacarato, A. M. (2000). Educação Continuada sob a Perspectiva da Pesquisa-Ação: Currículo em ação de um grupo de professoras ao aprender ensinando geometria [Continuing Education from the Action Research Perspective: Curriculum in action of a group of teachers learning how to teach geometry]. Ph.D. thesis. Universidade Estadual de Campinas, Brasil.

Oliveira, D. (2013). As Aprendizagens dos Professores que Ensinam Matemática para Crianças ao se Inserirem em um Espaço Formativo Sobre Estocástica [The Learning of Teachers who Teach Mathematics to Children within a Training Space for Stochastics]. $\mathrm{Ph} . D$. thesis in Science and Mathematics Teaching. Universidade Cruzeiro do Sul, Brasil.

Pamplona, A. S., \& Carvalho, D. L. (2011). A educação estatística e as relações de poder em comunidades de prática [Statistics education and the power relations in communities of practice]. Bolema, 24(39), 351-366. 
Perez, G. (1999). Formação de professores de matemática sob a perspectiva do desenvolvimento profissional. [Mathematics teachers' training from the perspective of professional development.] In M. A. V. Bicudo (Ed.), Pesquisa em Educação Matemática: Concepções \& perspectivas. (pp. 263-282). São Paulo, Brasil: Editora UNESP.

Placco, V. M. N. S., \& Souza, V. L. T. (Eds.) (2006). Aprendizagem do Professor Adulto [Learning for the adult teacher]. São Paulo, Brasil: Loyola.

Ponte, J. P. (1992). Concepções dos professores de Matemática e processor de formaçao. In J. P. Ponte (Ed.), Educação Matemática: Temas de investigação [Mathematics education: Research themes] (pp. 185-239). Lisboa, Portugal: Instituto de Inovação Educacional.

[Online: http://repositorio.ul.pt/bitstream/10451/2985/1/92-Ponte\%20(Concep\%C3\%A7\%C3\%B5es).pdf]

Shaughnessy, M. (1992). Research in probability and statistics: reflections and directions. In D. A. Grouws (Ed.), Handbook of research on mathematics teaching and learning (pp. 465494). New York: Macmillan Publishing Company.

Shaughnessy, M. (1996). Emerging issues for research on teaching and learning probability and statistics. In B. Philips (Ed.), Papers on Statistical Education presented at ICME-8. [Online: iase-web.org/documents/papers/icme8/Shaughnessy.pdf]

Silva, S. A. F. (2009). Aprendizagens de Professoras num Grupo de Estudos sobre Matemática nas Séries Iniciais [Teachers' Learning in a Mathematics Study Group in the Early Grades]. Ph.D. thesis in Education. Universidade Federal do Espírito Santo, Brasil.

Souza, A. C. (2007). A Educação Estatística na Infância [Statistics Education in Childhood]. Master's thesis in Science and Mathematics Teaching. Universidade Cruzeiro do Sul, Brasil.

Souza, A. C. (2013). O Desenvolvimento Profissional de Educadoras da Infância: Uma aproximação à educação estatística. [The Professional Development of Preschool Educators: An approach to statistics education.] Ph.D. thesis in Science and Mathematics Teaching. Universidade Cruzeiro do Sul, Brasil.

Statonato, S. C. (2010). A Formação dos Formadores: Uma análise do processo formativo [Educators' Education: An analysis of education process]. Master's thesis in Science and Mathematics Teaching. Universidade Cidade de São Paulo, Brasil.

Tardif, M., \& Raymond, D. (2000). Saberes, tempo e aprendizagem do trabalho no magistério [Knowledge, time and learning in teaching]. Educação \& Sociedade, 21(73), pp. 209-244. [Online: http://www.scielo.br/pdf/es/v21n73/4214.pdf]

Tereza, M. (2007). Negrices em Flor [Blossoming Blackness]. São Paulo, Brasil: Toró. [Online: http://www.edicoestoro.net/nossos-livros/14-publicados/33-negrices-em-flor-maria-tereza.html ]

ANTONIO CARLOS DE SOUZA

Rua Sérgio Roberto da Silva, 83 Jardim Santa Inês, Suzano São Paulo, Brasil CEP: 08695-015 